2. Walker J.L. The diffusion of innovations among American States. The American Political Science Review. 1969. Vol.63, No. 3. P. 880-899. URL: https://fbaum.unc.edu/teaching/PLSC541_Fall08/walker_1969.pdf

3. Rose R. What is Lesson-Drawing? Journal of Public Policy. 1991. Vol. 11, Issue 1. P. 3-30. URL: https://www.cambridge.org/core/journals/ journal-of-public-policy/article/abs/what-is-

lessondrawing/13FAAE1D377F7733A3BBDF3B7D826FD1

4. Ern Ser T., Parasuraman B. Globalization and National Industrial Relations Systems: Theoretical Implications from the Singapore Case. Asian Profile.2005. Vol. 33, No. 4. P. 343-350. URL: https://ro.uow.edu.au/cgi/ viewcontent.cgi?article $=2111 \&$ context $=$ commpapers

5. Strunz S., Gawel E., Lehmann P., Söderholm P. Policy convergence: A conceptual framework based on lessons from renewable energy policies in the EU. UFZ Discussion Papers. 2015. No. 14. P. 1-29. URL: https://www.ufz.de/export/data/global/84060_DP_14_2015_Strunzetal.pdf

6. Rowley C., Benson J. Convergence and Divergence in Asian Human Resource management. California Management Review. 2002. Vol. 44, No. 2. P. 90-109. URL: https://www.academia.edu/36483637/Convergence_and_ Divergence_in_Asian_Human_Resource_Management_California_Manage ment_Review_Reprint_Series

7. Knill C. Introduction: Cross-national policy convergence: concepts, approaches and explanatory factors. Journal of European Public Policy. 2005. Vol. 12. P. 764-774. URL: https://www.researchgate.net/publication/ 30015252_Introduction_Cross-National_Policy_Convergence_Concepts_ Approaches_and_Explanatory_Factors

DOI https://doi.org/10.30525/978-9934-26-147-3-3

\title{
ВПЛИВ ІНФОРМАЦІЙНИХ ТЕХНОЛОГІЙ НА ВИБОРЧІ ПРОЦЕСИ
}

\author{
Редчиць О. С. \\ аспірантка Навчально-наукового інституту публічного управління \\ та державної служби Київського національного університету \\ імені Тараса Шевченка \\ м. Київ, Україна
}

Функціонування мережі Інтернет напряму пов'язане 3 реалізацією основоположних прав людини, які відіграють головну роль у побудові демократичного суспільства, зокрема права на свободу інформації, 12 
вираження поглядів, думки, зібрань та об'єднань, а також права на захист приватності та персональних даних.

Розвиток інформаційних технологій змінюе спосіб спілкування та взаємовідносин між громадянами, представницькими органами влади, політичними партіями та органами адміністрування виборчих процесів.

Під інформаційними технологіями у виборчих процесах розуміється оцифрування (діджиталізація) документів і процедур, біометрія, блокчейн, хмарні обчислення, використання штучного інтелекту. За допомогою таких технологій зберігається та обробляється інформація в цифровому вигляді, їх принциповою особливістю $є$ складність та швидкий темп розвитку [1, с. 149].

Досягнення у комп'ютерній сфері та розвиток нових інформаційних технологій безпосередньо вплинули на механізм організації, підготовки та проведення виборів шляхом технологізації виборчих процесів.

Принципи та стандарти застосування інформаційних технологій під час виборчого процесу сформульовано в багатьох документах Ради Європи, ОБСЄ та інших міжнародних організацій.

До таких актів належать: Загальна декларація прав людини; Міжнародний пакт про громадянські та політичні права; Конвенція про захист прав людини та основоположних свобод та Протокол до неї; Конвенція про кіберзлочинність; Конвенція про захист осіб у зв'язку з автоматизованою обробкою персональних даних; Додатковий протокол до Конвенції про захист осіб у зв'язку з автоматизованою обробкою персональних даних щодо органів нагляду та транскордонних потоків даних; Конвенція про стандарти демократичних виборів, виборчих прав і свобод у державах-учасницях Співдружності Незалежних Держав; Рекомендація Комітету Міністрів Ради Свропи державам-членам щодо захисту недоторканності приватного життя в Iнтернеті Rec(99)5; Рекомендація Комітету Міністрів Ради Свропи державам-членам щодо електронного врядування (е-врядування) $\operatorname{Rec}(2004) 15$; Рекомендація Комітету Міністрів Ради Свропи державам-членам щодо електронної демократії (е-демократії) CM/Rec(2009)1.

Основні принципи, що стосуються виборів, викладено в Кодексі належної практики у виборчих справах Венеціанської комісії, зокрема встановлено, що неодмінною умовою застосування інформаційних технологій у виборах є забезпечення достовірності результатів виборів, довіри до результатів виборів з боку виборців, а також захищеність даних від несанкціонованого втручання [2].

Наразі основною тенденцією розвитку виборчого процесу у світі $\epsilon$ його насичення інформатизованими та автоматизованими електронними 
засобами голосування, онлайн-процедурою зміни місця голосування та електронною процедурою висування кандидатів на участь у виборах [3].

Міжнародний досвід впровадження інформаційних технологій у виборчі процеси різноманітний та охоплює також процес обліку суб'єктів виборчого процесу та автоматизованого підрахунку голосів із застосуванням електронних пристроїв та спеціального програмного забезпечення.

Такі виборчі процедури супроводжуються ретельною підготовкою законодавчого регулювання та охоплюють, аспекти, пов'язані зі закупівлею та тестуванням обладнання, аудитом та доступом громадськості до таких інформаційних технологій.

Разом із тим, інформаційні технології покращують та полегшують виборчі процеси, але також спричиняють появу нових викликів і ризиків. Впровадження таких технологій у виборчі процеси здатне підвищити ефективність та швидкість обробки даних, уникнути технічних помилок, проте може спричинити вразливість окремих виборчих процесів, відкрити виборчу систему для нових загроз і атак [4].

Використання інформаційних технологій може зробити виборчі процеси з однієї сторони більш доступними для всіх громадян, однак 3 іншої, може створити нові форми протиправного втручання, наприклад: у право голосу та право балотуватися на виборах, у право на свободу вираження поглядів та у право на повагу до приватного життя.

Застосування інформаційних технологій у виборчих процесах також може вплинути на результати виборів, підвищити рівень довіри громадян до демократичних інститутів та демократичних процесів, сприяти прозорості, підзвітності, чуйності, залученню, обговоренню, інклюзивності, доступності, субсидіарності та соціальній згуртованості громадян за умови дотримання високого рівня захищеності (кібербезпеки) таких інформаційних технологій.

Головними міжнародно-правовими стандартами захисту кібербезпеки $\epsilon-$ Конвенція про кіберзлочинність (Будапештська конвенція) та Конвенція Ради Європи про захист осіб у зв'язку з автоматизованою обробкою персональних даних (Конвенція 108+).

Органи адміністрування виборчих процесів повинні здійснювати контроль за впровадженням інформаційних технологій у виборчі процеси та гарантувати їх застосування у безпечний спосіб з метою дотримання принципів демократичних виборів за для гарантування загального, рівного, вільного виборчого права шляхом таємного голосування.

Однак, загрози при використанні інформаційних технологій постійно актуалізуються через дію таких чинників, як невідповідність 
інфраструктури рівню її розвитку та захищеності відповідно до сучасних вимог, та недостатнім розвитком організаційно-технічної інфраструктури забезпечення кібербезпеки та кіберзахисту.

В свою чергу, використання інформаційних технологій у виборчих процесах має і переваги, такі як зручність для виборців, прозорість та відкритість, можливість застосування у надзвичайних ситуаціях.

Втручання у вибори через зловмисну кібердіяльність, спрямовану проти комп'ютерів і даних, що використовуються у виборах і виборчих кампаніях, підриває вільні, чесні й чисті вибори та довіру до демократії [5, c. 143].

Таким чином, інформаційні технології залежать від рівня забезпечення кібербезпеки (нормативного регулювання сфери, заходів захисту даних, можливостей перевірки достовірності інформації, відповідальності за порушення, тощо).

Інформаційні технології - це інструмент, який може значно посилити демократичні процеси в країні.

Вплив інформаційних технологій на виборчі процеси залежить, поперше, від ступеня захищеності основних прав та свобод людини та громадянина.

По-друге, інформаційні технології у виборчих процесах здійснюють вплив на електоральну демократію, яку розуміють як інституційну діяльність та інфраструктуру, що роблять вибори можливими.

По-третє, мережа Інтернет та інформаційні технології мають потенціал забезпечити більшу прозорість і підзвітність, а також більш широкі та ефективні форми політичної участі громадян.

\section{Література:}

1. Ардіта Дріза Маурер. Цифрові технології у виборах. Питання, висновки та перспективи. Рада Європи, березень 2020 p. URL: https://rm.coe.int/publication-digital-technologies-regulations-ukr/168 09е8040 (дата звернення: 14.09.2021)

2. Кодекс належної практики у виборчих справах. Керівні принципи та пояснювальна доповідь, ухвалені Венеціанською комісією на 52-й сесії (Венеція, 18-19 жовтня 2002 року). URL: https://eos.cartercenter.org/uploads/document_file/path/279/CoE_ Venice_Commission_Code_of_Good_Practice_UK.pdf (дата звернення: 14.09.2021)

3. Редчиць О. С. Інформаційні механізми вдосконалення виборчих процесів в Україні. Вісник Національної академії державного управління при Президентові України № 2(97)/2020. URL: http:// visnyk-nadu.academy.gov.ua/ article/view/208300 (дата звернення: 15.09.2021) 
4. Compendium on Cyber Security of Election Technology. July 2018. URL: https://www.ria.ee/sites/default/files/content-editors/kuberturve/cyber_ security_of_election_technology.pdf?fbclid=IwAR2bptHm1_-OGOEYs9jcFHLbSPJaM6oJ4QxzrnzvqB7wBMjfyWtPjmfTBU (дата звернення: 16.09.2021)

5. Керівна настанова щодо виборів. Ухвалена Комітетом з питань Конвенції про кіберзлочинність (Т-CY) на 21-ому засіданні 8 липня 2019 року. URL: https://rm.coe.int/elections-digital-technologies-humanrights/ 16809fa91c (дата звернення: 16.09.2021)

DOI https://doi.org/10.30525/978-9934-26-147-3-4

\title{
ВПЛИВ ПОПУЛІЗМУ НА ДИНАМІКУ ЗМІН У ПУБЛІЧНОМУ СЕКТОРІ
}

\author{
Семенець-Орлова I. А. \\ доктор наук з державного управління, доцент, \\ завідувач кафедри публічного адміністрування \\ Міжрегіональної академії управління персоналом \\ м. Київ, Україна
}

Сучасний популізм $\epsilon$ результатом перетворення політики на маркетинг. Популістський світогляд простий: загалом світ поділяється на широкі групи порядних «простих людей» та корумповану «еліту». Таким чином, популіст підживлює свою політичну активність антиелітарними настроями, теоріями змови «людей при владі» та невдоволенням тенденцією глобалізації. Крім того, важливим компонентом популізму є недовіра людей до інших політиків та інституцій, навіть якщо ці інститути є демократичними.

Сьогодні світ має безліч причин для зростання популярності популістських настроїв. Він стає дедалі складнішим, традиційне політичне поле змінюється, і політичні партії все менше спираються на політичні переконання («ліві» чи «праві»). Окрім того, традиційні політичні партії із власною перевіреною десятиліттями інфраструктурою руйнуються. Вони втрачають осередки, активістів, ідеологію та джерела фінансування i, тим самим, звільняють простір для нових сил.

Звичайно, популіст репрезентує себе, насамперед, як представника «маленьких» чесних людей, інтереси яких недостатньо представлені. Крім того, він пропонує прості рішення складних проблем. Як зазначив історик Р. Хофстедтер, історичне значення феномену популізму поля16 